\section{Fertilization Rate Affects Production and Postharvest Quality of Tapeinochilus ananassae Flowers}

\author{
Timothy K. Broschat \\ University of Florida, Fort Lauderdale Research and Education Center, 3205 \\ College Avenue, Fort Lauderdale, FL 33314
}

Additional index words. tropical cut flowers, Indonesian wax ginger, postharvest handling

\begin{abstract}
Greenhouse-grown Tapeinochilus ananassae Hassk. were fertilized with 1110, 2220 , or $4440 \mathrm{~g}$ of Osmocote $17 \mathrm{~N}-3 \mathrm{P}-10 \mathrm{~K} / \mathrm{m}^{2}$ per year for 4 years. Plants receiving the medium rate of fertilizer produced the most flowers, while the highest fertilization rate resulted in the fewest. Flower stalk length decreased each year after planting, but cutting back the vegetative shoots to the ground resulted in increased flower stalk length the following year. Fertilization with the highest rate resulted in reduced flower postharvest life, but floral preservatives and ethylene inhibitors had no effect on postharvest life.
\end{abstract}

Tapeinochilus ananassae, commonly known as Indonesian wax ginger, is often cultivated in tropical regions of the world for its large, brilliant red, stiff inflorescences that are produced at the tip of leafless flower stalks. Although it has been grown commercially for cut flowers for more than a decade, there has been no research to date on the production or postharvest handling of this crop. Two of the problems limiting the acceptance of this flower by florists are the frequency of very short $(<30$ $\mathrm{cm})$ flower stalks and the brevity of vase life. The purpose of this study was to determine the effects of fertilization rate and other factors on flower production and quality.

\section{Materials and Methods}

Five 2.9-liter containers of $T$. ananassae were planted on 12 Sept. 1988 into each of 12 raised beds filled to a depth of $30 \mathrm{~cm}$ with a 5 pine bark : 4 sedge peat : 1 sand medium amended with $4.9 \mathrm{~kg}$ of dolomite and $880 \mathrm{~g}$ of Micromax $/ \mathrm{m}^{3}$ (Grace-Sierra, Milpitas, Calif.). Beds measured $0.75 \times 2 \mathrm{~m}$ and were arranged in four rows of three beds each. Rows of beds were $70 \mathrm{~cm}$ apart and were located in a fiberglass-covered greenhouse that provided a maximum photosynthetic photon flux of 870 $\mu \mathrm{mol} \cdot \mathrm{m}^{-2} \cdot \mathrm{s}^{-1}$. Osmocote (Grace-Sierra) $17 \mathrm{~N}$ $3 \mathrm{P}-10 \mathrm{~K}$ was surface-applied twice per year at 1110,2220 , and $4440 \mathrm{~g} / \mathrm{m}^{2}$ per year. Treatments were arranged in a randomized complete-block design. Flower stalks were cut $\approx 8$ $\mathrm{cm}$ aboveground every 3 to 4 weeks during the production season, and stalk length was measured. Data were analyzed by linear regression or analysis of variance (ANOVA). On 9 Nov.

Received for publication 24 Aug. 1994. Accepted for publication 10 Mar. 1995. Florida Agricultural Experiment Station Journal series no. R-04027. The cost of publishing this paper was defrayed in part by the payment of page charges. Under postal regulations, this paper therefore must be hereby marked advertisement solely to indicate this fact.
1989, two rows of beds were cut back to ground level and two rows were thinned by cutting out all vegetative stems $>2 \mathrm{~m}$ in length. On 22 July 1990, all beds were cut back to ground level in an attempt to rejuvenate the plants.

In June 1989 and Apr. and May 1990, flowers from each fertilizer treatment were placed into deionized (DI) water in a typical interior environment maintained at $23 \mathrm{C}$ to determine postharvest life. In this series of repeated experiments, postharvest life was determined either at their natural flower stalk length (two experiments) or with stalks cut to 25,50 , or $100 \mathrm{~cm}$ in length (three experiments). Fifty flowers were used for each of the natural stalk length experiments and 10 replicate flowers per fertilizer rate-stem length treatment were used in the second set of experiments. Flowers were considered senesced when $>1 \mathrm{~cm}$ of necrosis was observed on a single bract. Necrosis or rotting of the entire inflorescence usually occurred the following day.

Tapeinochilus flowers are usually harvested when inflorescence length is equal to or slightly less than its diameter, but if not harvested, they will continue to elongate for 1 to 2 months and eventually attain a length of $30 \mathrm{~cm}$ or more. To evaluate the effects of age at cutting on postharvest life, an additional 30 flowers ranging from 10 to $20 \mathrm{~cm}$ in length were similarly maintained in DI in an interior environment.

The effects of several postharvest treatments on flower vase life were tested using 10 replicate flowers with stems cut to $30 \mathrm{~cm}$. of Tapeinochilus ananassae.
Treatments were 1) DI water control, 2) $9 \mathrm{~g}$ Floralife/liter (Floralife, Chicago), 3) a 4-h pulse in $2.0 \mathrm{~mm}$ silver thiosulfate (STS) followed by holding in DI water, and 4) a 2-min pulse in 25 ppm benzyladenine (BA) followed by holding in DI water. An additional 10 flowers were placed in covered mason jars containing $400 \mathrm{ml}$ of DI, and their daily water uptake and fresh weight loss were monitored. Data were analyzed by ANOVA with mean separation by the Waller-Duncan $\mathrm{k}$ ratio method.

\section{Results and Discussion}

Flower production began about 1 May 1989, with flowers reaching a marketable stage $\approx 37$ days after shoot emergence from the soil. The number of flowers per square meter produced during each of the 4 years was highest for those beds fertilized with $2220 \mathrm{~g}$ of Osmocote $17 \mathrm{~N}$ $3 \mathrm{P}-10 \mathrm{~K} / \mathrm{m}^{2}$ per year (Table 1). Increasing fertilization rate to $4440 \mathrm{~g} / \mathrm{m}^{2}$ per year resulted in the fewest flowers produced, but stems were longest at this fertilizer rate during most years. In established beds, flower production generally began in March or April and extended through September with a peak in June (Fig. 1). Environmental factors responsible for this seasonality in flowering are not known.

Cutting the vegetative stems back to the ground in Nov. 1989 resulted in no flower production the following year, but 26.9 flow$\mathrm{ers} / \mathrm{m}^{2}$ were produced in those beds where only tall $(>2 \mathrm{~m})$ stems were removed $(P<$ 0.0001 ) (data not shown). Those flowers, however, typically had unacceptably short stalks $($ mean $=52.9 \mathrm{~cm})$. When plants in all beds were cut back to the ground in July 1991, all plants flowered the following year (1992) and flower stalks were $40 \%$ to $100 \%$ longer than before they had been cut back (Table 1). There was a significant correlation between flower density and stalk length only during 1989. Although increasing plant age (from cut back) may be an important factor in reducing flower stalk length, and late-summer (vs. fall) cut backs appear preferable to obtain flower production the following year, additional experiments are needed to test these hypotheses.

Postharvest life for all flowers averaged $<1$ week during the first year of production, but 14 days in the second and subsequent years (data not shown). A similar phenomenon was reported for Alpinia purpurata (Viell.) K. Schum. (Broschat and Donselman, 1988). Unlike with Alpinia, however, there was no association between stem length and postharvest life of cut $T$. ananassae flowers (data not shown), nor was there an association be-

Table 1. Effects of fertilization with Osmocote $17 \mathrm{~N}-3 \mathrm{P}-10 \mathrm{~K}$ at three rates on flower number and stalk length

\begin{tabular}{|c|c|c|c|c|c|c|c|c|}
\hline \multirow{2}{*}{$\begin{array}{l}\text { Fertilization } \\
\text { rate } \\
\left(\mathrm{g} / \mathrm{m}^{2} \text { per year }\right)\end{array}$} & \multicolumn{2}{|c|}{1989} & \multicolumn{2}{|c|}{1990} & \multicolumn{2}{|c|}{1991} & \multicolumn{2}{|c|}{1992} \\
\hline & $\begin{array}{c}\text { No. } \\
\text { flowers } / \mathrm{m}^{2}\end{array}$ & $\begin{array}{l}\text { Length } \\
(\mathrm{cm})\end{array}$ & $\begin{array}{c}\text { No. } \\
\text { flowers } / \mathrm{m}^{2}\end{array}$ & $\begin{array}{l}\text { Length } \\
(\mathrm{cm})\end{array}$ & $\begin{array}{c}\text { No. } \\
\text { flowers } / \mathrm{m}^{2}\end{array}$ & $\begin{array}{l}\text { Length } \\
(\mathrm{cm})\end{array}$ & $\begin{array}{c}\text { No. } \\
\text { flowers } / \mathrm{m}^{2}\end{array}$ & $\begin{array}{l}\text { Length } \\
(\mathrm{cm})\end{array}$ \\
\hline$\overline{1110}$ & 17.0 & 97.0 & 25.5 & 50.5 & 36.8 & 56.8 & 25.5 & 115.8 \\
\hline 2220 & 20.8 & 99.1 & 32.0 & 49.8 & 39.0 & 55.5 & 39.5 & 114.2 \\
\hline 4440 & 12.5 & 119.7 & 23.0 & 58.8 & 30.3 & 69.8 & 17.0 & 98.6 \\
\hline Significance $(P)$ & 0.025 & 0.020 & 0.046 & 0.067 & 0.062 & 0.014 & 0.048 & 0.078 \\
\hline
\end{tabular}




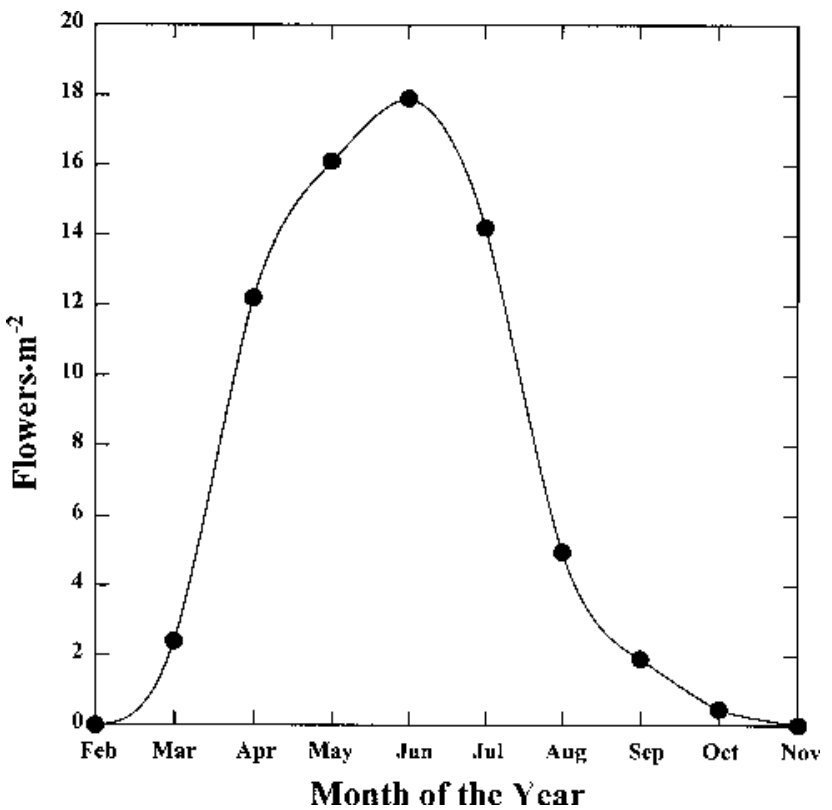

Fig. 1. Seasonal distribution of flower production in Tapeinochilus ananassae averaged over 4 years.

Table 2. Effects of floral preservatives and ethylene inhibitors on postharvest life of cut Tapeinochilus ananassae flowers.

\begin{tabular}{llc}
\hline \hline Pulsing solution & Holding solution ${ }^{\mathrm{z}}$ & $\begin{array}{c}\text { Postharvest life } \\
\text { (days) }\end{array}$ \\
\hline None & DI & $15.7 \mathrm{a}^{\mathrm{y}}$ \\
$2.0 \mathrm{~mm}$ STS $(4 \mathrm{~h})$ & DI & $12.4 \mathrm{~b}$ \\
$110 \mu \mathrm{m} \mathrm{BA}(2 \mathrm{~min})$ & DI & $16.1 \mathrm{a}$ \\
None & Floralife $\left(9 \mathrm{~g} \cdot\right.$ liter $\left.^{-1}\right)$ & $14.1 \mathrm{ab}$ \\
\hline
\end{tabular}

${ }^{2} \mathrm{DI}=$ deionized water.

${ }^{\mathrm{y}}$ Mean separation by the Waller-Duncan $\mathrm{k}$ ratio method, $\mathrm{k}=100$. tween inflorescence age and postharvest life. As with flower production, optimum postharvest life (11.5 days) in 1989 was obtained from plants fertilized at $\left(\mathrm{g} / \mathrm{m}^{2}\right.$ per year) $2220(11.5$ days), but the highest rate (4440) significantly reduced postharvest life (5.4 days); postharvest life was 9.3 days at 1110 (significance at $P \leq 0.0001)$. In subsequent years, fertilization rate had no effect on postharvest life of cut $T$. ananassae flowers (data not shown).

None of the floral preservatives or ethylene inhibitors tested increased postharvest life of cut $T$. ananassae flowers, but some materials, such as STS, decreased postharvest life relative to the controls and may have been phytotoxic (Table 2). Flowers lost an average of $6.6 \mathrm{~g}$ of fresh weight/day, but took up $5.6 \mathrm{ml}$ of water/day, suggesting that water stress may be a significant factor in the senescence of these flowers.

\section{Literature Cited}

Broschat, T.K. and H. Donselman. 1988. Production and postharvest culture of red ginger in south Florida. Proc. Fla. State Hort. Soc. 101:326-327. 